\title{
Relationship between Economy and Environment of the Natural Rubber Plantation in Major Producers
}

\author{
Yahya Shafiyuddin Hilmi ${ }^{1}$, Nurul Amri Komarudin ${ }^{2}$, and Elsera Br Tarigan ${ }^{3}$ \\ ${ }^{1}$ Department of Agricultural Socio-economics, Faculty of Agriculture, Universitas Gadjah Mada, \\ Sleman, Special Region of Yogyakarta 55281, Indonesia \\ ${ }^{2}$ Natural Resources and Environmental Management Sciences, Graduate School, Kampus IPB \\ Baranangsiang, Bogor, West Java 16129, Indonesia \\ ${ }^{3}$ Indonesian Industrial and Beverage Crops Research Institute, Ministry of Agriculture Republic \\ Indonesia, Bogor, West Java 16111, Indonesia
}

\begin{abstract}
Thailand, Indonesia, Viet Nam, and India are the major natural rubber producers to date. Natural rubber has become one of the largest export commodities in these countries. It creates job opportunities for the smallholders as well as contributes to the national economy growth. However, a large-scale of natural rubber plantation results in environmental issues such as the nitrous oxide $\left(\mathrm{N}_{2} \mathrm{O}\right)$ emission which is obtained from the use of synthetic fertilizer during the cultivation process. The postulate of Environmental Kuznets Curve (EKC) was employed to examine the relationship between economy and environment from the natural rubber plantation in major producers using secondary data ranging from 2005 to 2018. Therefore, the $\mathrm{N}_{2} \mathrm{O}$ emission in which represents environmental degradation was regressed with the value of natural rubber production as the proxy for the economy growth using a fixed effect model on the panel data regression analysis. Results show that there is an inverted U-shape curve from the relationship between the $\mathrm{N}_{2} \mathrm{O}$ emissions and the value of natural rubber production. Hence, this study supports the postulate of EKC's hypothesis. In addition, results found that the average value of natural rubber production from major producers was not yet reached the turning point of EKC. Some suggestions were made in order to increase the productivity while maintaining yet reducing the emission obtained from the use of synthetic fertilizer during cultivation process.
\end{abstract} Keywords: Environmental Kuznets Curve, Fertilization, Natural rubber, $\mathrm{N}_{2} \mathrm{O}$ emission, Value of natural rubber production

\section{Introduction}

Even though natural rubber is not the source of many food-products, we still need it as it can be easily found in tires, shoe soles, balloons, rubber boots, and any other things that rela ted to human living. As the needs of automotive are increasing, the demand for natural rubber,

\footnotetext{
* Corresponding author: yahya.shafiyuddin.h@gmail.com
} 
which around $70 \%$ of the productions was used for tires industry, is also increasing. The United States (US), China, and European Union (EU) a re the top importers of natural rubber because of their huge number of tires production industries, whereas many of the South East Asian countries have been exporting natural rubber products since more than a decade.

Rubber is a crop which can be usually found on several countries in the tropics. It was originated from Amazon Basin in Americas, few countries in West Africa, and Southeast Asia as well as the Indian sub-continent [1]. Due to the high global rubber demand, the area of rubber plantations worldwide is gradually increased from 3 million ha in 1961 to 12 million ha in 2019 [2]. From the production side, several Asian countries such as Thailand, Indonesia, Viet Nam, and India are the major natural rubber producers with the $73 \%$ cumula tive share of the global production as well as the highest net production value in recent years $[3,4]$.

As a commercialcommodity, rubber is not only meet the domestic demand but a lso look for the overseas rubber demand. It has an important role in gaining income through the foreign exchange of the major rubber producing countries [5]. Therefore, in the past few years, policy has been changed to promote the industrial export activity and successfully introduced natural rubber as one of the largest agricultural export commodities besides oil palm, coffee, and cocoa [6]. Thailand, Indonesia, and Cote d'Ivoire are the largest natural rubber exporting countries with the share of $31.5 \%, 29.8 \%$, and $8.4 \%$, respectively [7]. Whereas, developed countries such as United States, China, and Germany are the largest natural rubber importing countries in the world which processed the natural rubber products to various consumer's goods.

However, the expansion activity from the agriculture industry can contribute to the greenhouse gas emissions (GHG). As we might know, GHG have become a fairly prominent issue in the last few decades. There has been a significant increase in the number of GHG in the atmosphere since the industrial era due to human (anthropogenic) activities. There are six main compounds of GHG; carbon dioxide $\left(\mathrm{CO}_{2}\right)$, methane $\left(\mathrm{CH}_{4}\right)$, nitrous oxide $\left(\mathrm{N}_{2} \mathrm{O}\right)$, hydrofluorocarbon (HFC), perfluorocarbons (PFC), and sulphur hexafluoride ( $\left.\mathrm{SF}_{6}\right)$ [8]. In 2010 , a griculture sector has contributed to $24 \%$ of global GHG emission that is mostly comes from the activities in the cultivation of crops and livestock as well as the deforestation [9].

In order to increase productivity, a rubber plantation is always in need of fertilizers. The large-scale plantation means that it needs large number of fertilizers. Therefore, it is necessary for conducting the fertiliza tion management practice in rubber plantations in which often considered only from a single perspective; economic efficiency. However, the lack of emission-friendly synthetic fertilizer may harm the environment by relea $\operatorname{sing} \mathrm{N}_{2} \mathrm{O}$ emissions. As one of the GHG compounds, $\mathrm{N}_{2} \mathrm{O}$ can be found from the use of synthetic fertilizers during the cultivation process [10]. The fertilization activities can release $\mathrm{N}_{2} \mathrm{O}$ emissions by the chemical transformation processes in the soil.

The relationship between environmental degradation and economic activity can be explained by the EnvironmentalKuznets Curve (EKC). The curve assumed that the increase in economic activity can stimulate the increase of emission produced by the activity, even though the emission will start to decline if an amount of economic income has been reached by the producers. Therefore, the relationship coming from the hypothesis will form an inverted U-shaped curve [11]. As it explained by [12], the EKC can be divided in to three stages, in which the first stage is where a country only focused on the production aside from the environmental impact. After a country reaches some amount of income, which is the second stage, there is an increase at decreasing rate in environmentaldegradation. Then, the last stage is a country will start to inventing new technology and reducing the environmental impact.

A huge number of authors have studied the EKC hypothesis in which several have studied from the perspective of a griculture [13-19]. However, a specific study about the environment 
and economy related to the natural rubber plantations is rarely conducted. As one of the commodities that a re beneficial to the country's economic growth, the natural rubber industry is related to the negative impact coming from the use of synthetic fertilizer in large-scale natural rubber plantations. Therefore, this study aims to examine the relationship between the $\mathrm{N}_{2} \mathrm{O}$ emissions from the use of synthetic fertilizer and the value of natural rubber production in Thailand, Indonesia, Viet Nam, and India.

\section{Material and methods}

\subsection{Study site and data source}

The study sites were selected using purposive sampling methods; which was considering the location-specific condition regarding needs of the study. Known as the top four countries with the largest natural rubber net production value, Thailand, Indonesia, Viet Nam, and India were chosen based on their contribution to the global production. In addition, these four countries are having an increasing rate of natural rubber production.

Aside from time series data, this study also employs paneldata, which is the combination of the time series and cross-sectional data, a imed for the better analysis results with bigger sample size and minimizing bias [20]. The secondary data of the $\mathrm{N}_{2} \mathrm{O}$ emissions, the production of natural rubber, and the value of natural rubber production during the period of 2005 to 2018 were collected from Food and Agricultural Organization Statistical Data or FAOSTAT (http://www.fao.org/faostat/en/\#data). Regarding the needs of this study, the collected data therefore has been recalculated.

\subsection{The Trends of $\mathrm{N}_{2} \mathrm{O}$ Emission from Natural Rubber Plantations in Major Producers}

The collected time series data was employed to examine the trends of $\mathrm{N}_{2} \mathrm{O}$ emission from natural rubber plantations in each country using Linear Regression Method. Following the theory in [21], the equation model can be written as follows:

$$
Y=\beta_{1}+\beta_{2} t+u_{t}
$$

Where $Y$ is the dependent variable, $\beta_{1}$ is the intercept, $\beta_{2}$ is the time change regression coefficient or slope, and t is the time trend variable (i.e., $2005=1,2006=2,2007=3$, etc). Following the first objective, therefore the hypothesis is that $\beta_{2}$ is positive or it can be written as: $0>\beta_{2}>1$.

\subsection{The Analysis of Relationship between $\mathrm{N}_{2} \mathrm{O}$ Emission and the Value of Natural Rubber Production}

In order to examine the relationship between environmental degradation and economic activity, we employ the hypothesis of Environmental Kuznets Curve (EKC). The EKC model will explain whether a state or a country has reached some particular stage to show their income allocation to improve the environmental condition. Initially, a country will focus on increasing their production, thus they might also increase the environmental degradation as they have not been really concerned about the environment. However, if the country has reached a particular a mount of income, they will allocate their income and start to improve their environment by inventing and a dopting new technology that can produce lower a mounts of emission [12]. 
This study has modified the EKC equation model from [13], therefore the basic model can be written as follows:

$$
N_{2} O_{i t}=\beta_{0}+\beta_{1} V P R+\beta_{2} V P R^{2}+\varepsilon_{i t}
$$

Where $i$ denotes countries, $t$ denotes period of time, $\mathrm{N}_{2} \mathrm{O}$ is the a mount of $\mathrm{N}_{2} \mathrm{O}$ emission obtained from the use of synthetic fertilizer in natural rubber plantations measured in tonne of $\mathrm{CO}_{2}$-equivalent per hectares per year, $V P R$ is the production value of natural rubber measured in USD per tonne per year, and $V P R^{2}$ is the square of the production value of natural rubber.

Because this study employs panel data, we need to choose the best model amongst two possible models which are the common effect model or known as the ordinary least square (OLS), the fixed effect model, and the random effect model. Furthermore, the best model is tested through Chow test and Hausman test.

\section{Results and discussions}

\subsection{The Trends of $\mathrm{N}_{2} \mathrm{O}$ Emission from Natural Rubber Plantations in Major Producers}

Results from the linear regression trend analysis shows that the $\mathrm{N}_{2} \mathrm{O}$ emission obtained from the use of synthetic fertilizer during natural rubber cultivation process in four major producing countries are gradually increasing. This condition is in line with the increase in the fertilizer usage during the natural rubber cultiv ation process. Following are the figures of the trends of $\mathrm{N}_{2} \mathrm{O}$ emission from each country in the period of 2005 to 2018 .

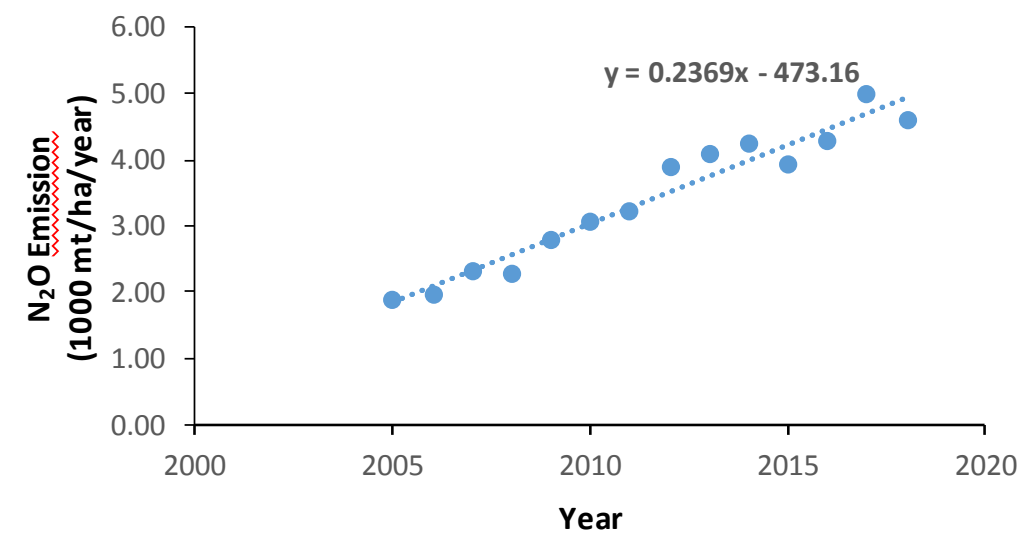

Fig. 1. The trends of $\mathrm{N}_{2} \mathrm{O}$ emission obtained from natural rubber plantations in Thailand 


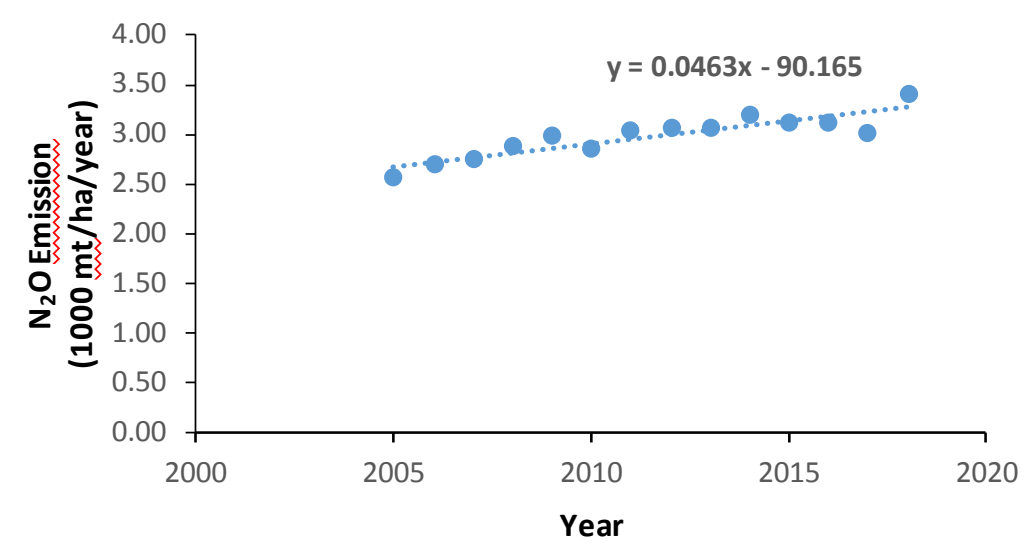

Fig. 2. The trends of $\mathrm{N}_{2} \mathrm{O}$ emission obtained from natural rubber plantations in Indonesia

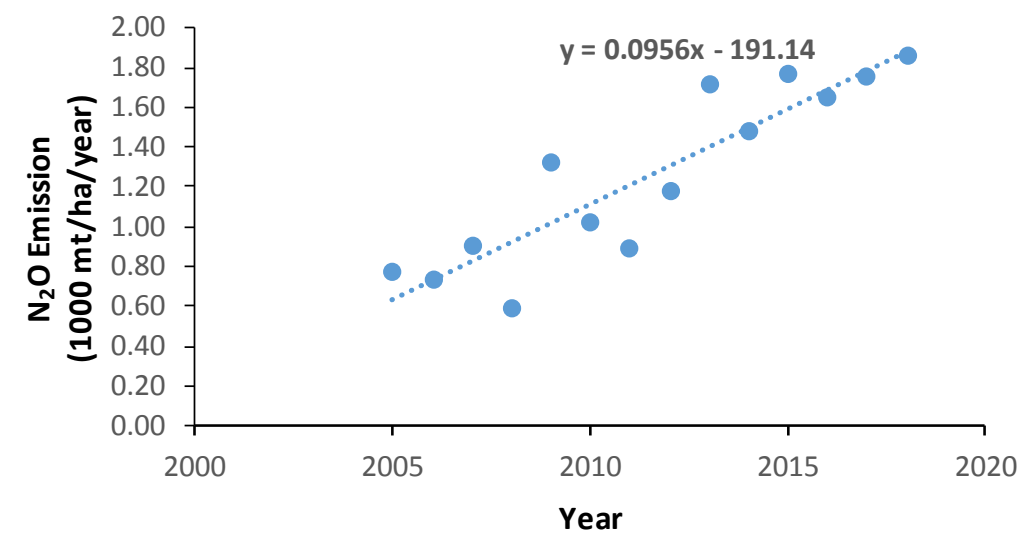

Fig. 3. The trends of $\mathrm{N}_{2} \mathrm{O}$ emission obtained from natural rubber plantations in Viet Nam. 


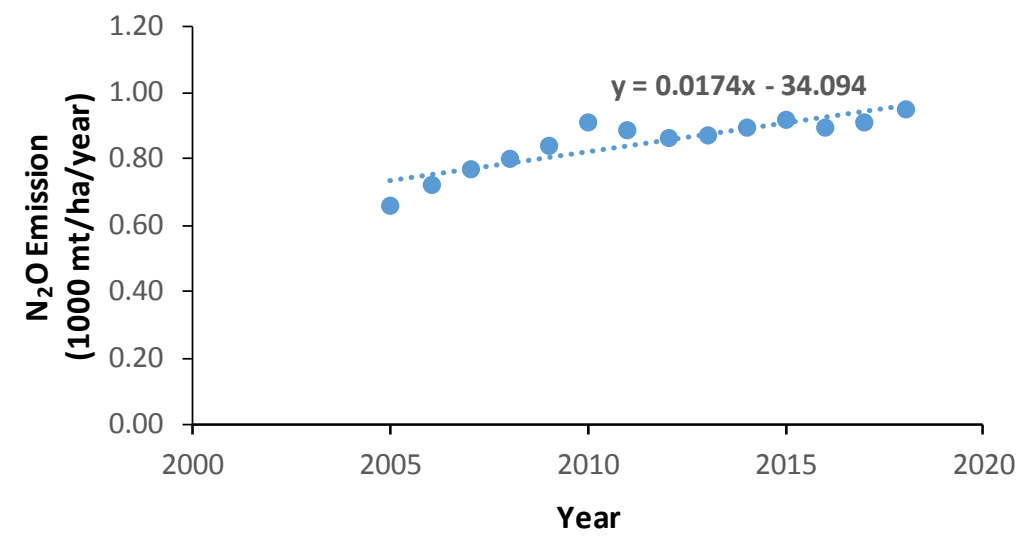

Fig. 4. The trends of $\mathrm{N}_{2} \mathrm{O}$ emission obtained from natural rubber plantations in India.

Table 1 shows the rate of applied synthetic fertilizer on the natural rubber plantation in four major producing countries.

Table 1. The rate of applied synthetic fertilizer on the natural rubber plantation in Thailand, Indonesia, Viet Nam, and India

\begin{tabular}{|c|c|c|c|c|}
\hline Year & Thailand & Indonesia & Viet Nam & India \\
\hline 2005 & 90,855 & 152,562 & 36,619 & 31,576 \\
\hline 2006 & 94,880 & 128,910 & 34,997 & 34,726 \\
\hline 2007 & 111,715 & 131,093 & 43,089 & 36,843 \\
\hline 2008 & 108,674 & 171,211 & 28,319 & 38,285 \\
\hline 2009 & 133,117 & 181,388 & 63,209 & 40,436 \\
\hline 2010 & 147,220 & 172,539 & 48,753 & 43,698 \\
\hline 2011 & 154,130 & 179,462 & 42,262 & 42,532 \\
\hline 2012 & 186,724 & 181,731 & 56,027 & 41,387 \\
\hline 2013 & 195,957 & 174,116 & 82,233 & 41,946 \\
\hline 2014 & 203,547 & 184,071 & 71,061 & 42,911 \\
\hline 2015 & 187,478 & 178,123 & 84,365 & 44,089 \\
\hline 2016 & 204,773 & 179,086 & 79,070 & 42,958 \\
\hline 2017 & 238,751 & 173,380 & 83,915 & 43,663 \\
\hline
\end{tabular}




\begin{tabular}{|c|c|c|c|c|}
\hline 2018 & 219,654 & 190,764 & 89,117 & 45,396 \\
\hline Avg. Growth Rate (\%) & 7.47 & 2.22 & 12.46 & 2.90 \\
\hline
\end{tabular}

Source: [22], calculated

In 2019, Viet Nam has highest growth rate of the net rubber production compared to Thailand, Indonesia, and India [3]. One of the factors that a ffect production is fertilization. Table 1 show that Viet Nam has highest average growth rate of applied fertilizer on their natural rubber plantations valued at $12.46 \%$ compared to the other major producing countries. On the other side, the average growth rate of applied fertilizer on the natural rubber plantations in Indonesia and India are only around 2 to 3\%, whereas Thailand has $7 \%$ of the a verage growth rate of applied fertilizer.

With the interpretation from Table 1, it can be related to the above figures, in which Viet Nam has steepest slope than the other countries (See Figure 3). It means that Viet Nam has the largest $\mathrm{N}_{2} \mathrm{O}$ emission from the use of synthetic fertilizer during the natural rubber cultivation process. A paper studied the greenhouse gas emission sourced from the use of synthetic fertilizer on oil palm plantations. They found that the increase in the rate of nitrogen-based synthetic fertilizer applied during cultivation process will significantly affects the number of $\mathrm{N}_{2} \mathrm{O}$ emission [23].

Figure 2 and 4 shows that the $\mathrm{N}_{2} \mathrm{O}$ emission from the use of synthetic fertilizer in Indonesia and India are just gradually increasing. With the average growth rate of applied fertilizer valued at $2.22 \%$ and $2.90 \%$, the slope of $\mathrm{N}_{2} \mathrm{O}$ emission on both countries are not as steep as Viet Nam's. Even though the number of $\mathrm{N}_{2} \mathrm{O}$ emission from natural rubber plantations in Indonesia is higher than Viet Nam's, Indonesia has the less steep slope compared to the others. It means that the $\mathrm{N}_{2} \mathrm{O}$ emission from the use of synthetic fertilizer during natural rubber cultivation process in Viet Nam can be higher than Indonesia's if it is not carefully controlled and managed.

Results show that there will be increase on the environmental degradation by the release of $\mathrm{N}_{2} \mathrm{O}$ emissions obtained from the use of synthetic fertilizer on the rubber plantations. However, if the fertilization is not carried out, it is feared that it will reduce rubber productivity and will also cause a decrease in land fertility in the future. According to [24], the factors that influence the success of rubber plant fertilization include; dosage of fertilizer in sufficient a mount, type of fertilizer a ccording to plant needs, timing, frequency and proper fertilization method, as well as control of weeds and diseases.

In order to achieve the efficiency of fertilizer application in rubber plantations, several aspects must be carefully considered, especially in the preparation of fertilizer recommendation dosages. One of the aspects is the soil nutrient which is related to soil capacity to provide nutrients for plants, environmentalfactors such as weed conditions that affect fertilization efficiency, and the need for a specific nutrient according to age, production and condition of a plant. Therefore, [25] explained the importance of the analysis of soil and plant leaves in a certain area which is often called the LSU (Leaf Sampling Unit). The fertilizer recommendations for a better rubber plant cultivation can be made based on the general dosa ge of experimental results, soil nutrient index, leaf nutrient index, disea se attack index, wind disturbance index and nutrients depleted due to increased production [26]. 


\subsection{The Analysis of Relationship between $\mathrm{N}_{2} \mathrm{O}$ Emission and the Value of Natural Rubber Production}

EViews 10 software was employed in order to select the best model of a paneldata regression between common effect model, fixed effect model, and random effect model. Results found that the fixed effect model is the best model to be used in this study based on the Chow test and Hausman test. The model explained that the relationship between $\mathrm{N}_{2} \mathrm{O}$ emission and the value of natural rubber production forms an inverted U-shaped curve. It means that the relationship supports the EKC's hypothesis.

Following are the results of Chow test and Hausman test as shown in Table 2 and Table 3 , respectively.

Table 2. Results from the Chow test analysis

\begin{tabular}{|l|c|c|c|}
\hline Effect Test & Statistic & d.f. & Prob. \\
\hline Cross-section F & $198.230663^{*}$ & $(3,50)$ & 0.0000 \\
\hline Cross-section Chi-square & $143.177981^{*}$ & 3 & 0.0000 \\
\hline
\end{tabular}

* Significant at 0.05 alpha

Table 3. Results from the Hausman test analysis

\begin{tabular}{|l|c|c|c|}
\hline Effect Test & Chi-Sq. Statistic & Chi-Sq.d.f. & Prob. \\
\hline Cross-section random & $22.918008^{*}$ & 2 & 0.0000 \\
\hline
\end{tabular}

* Significant at 0.05 alpha

Based on Table 2, we found that the probability of the cross-section chi-square valued at 0.000 is less than alpha $0.05(0.000<\alpha)$. That means we can reject the null hypothesis; therefore, the fixed effect model is better than the common effect model based on Chow test analysis. Similar result was found in the Hausman test analysis. Table 3 shows that the probability of the cross-section random valued at 0.000 is less than alpha $0.05(0.000<\alpha)$ and it has successfully rejected the null hypothesis. Based on this analysis, the fixed effect model is better than the random effect model. Further interpretation of the analysis with the fixed effect model is shown in Table 4.

Table 4. The estimation of EKC using fixed-effect model

\begin{tabular}{|l|c|c|c|c|}
\hline Variables & Coefficient & Std. Error & t-Statistic & Prob. \\
\hline Constant & $-0.607864 *$ & $2.29 \times 10^{-7}$ & 5.784415 & 0.0846 \\
\hline VPR & $1.32 \times 10^{-6 * * *}$ & $2.19 \times 10^{-14}$ & -1.778129 & 0.0000 \\
\hline VPR $^{2}$ & $-3.89 \times 10^{-14 *}$ & 0.345417 & -1.759800 & 0.0815 \\
\hline F-statistic & $298.2453^{* * *}$ & & & \\
\hline
\end{tabular}




\begin{tabular}{|l|l|l|l|l|}
\hline Adj-R ${ }^{2}$ & 0.964314 & & & \\
\hline
\end{tabular}

*** Significant at 0.01 alpha

** Significant at 0.05 alpha

* Significant at 0.10 alpha

The model has the adjusted R-square valued at 0.964314 which means that $96.43 \%$ of the variation of the dependent variable, which is the number of $\mathrm{N}_{2} \mathrm{O}$ emissions, can be explained by the independent variables. Findings also show that the model demonstrates a quadratic function between $\mathrm{N}_{2} \mathrm{O}$ emission and the value of natural rubber production which has the $\mathrm{F}$ statistic valued at 298.2453 and is significant at alpha 0.01 . It means that the fixed effect model is appropriate for explaining the relationship between three variables. It is supported by the previous study that have successfully found some evidences to the existence of EKC in lower middle income in Africa using fixed effect model [27]. The two independent variables used in this study, notated with VPR and VPR ${ }^{2}$, a re also significant at alpha 0.01 and 0.10 , respectively. Based on the results, the equation model of the relationship between $\mathrm{N}_{2} \mathrm{O}$ emission and the value of natural rubber production can be written as follows:

$$
N_{2} O_{i t}=1.32 * 10^{-6} V P R-3.89 * 10^{-14} V P R^{2}-0.608
$$

Following the theory of EKC, the analysis results in an inverted U-shaped curve as we found both positive and negative coefficients of $\beta_{1}$ and $\beta_{2}$ which are also statistically significant. According to [12], the results support the postulate of EKC's hypothesis only if $\beta_{1}>0$ and $\beta_{2}<0$. This finding is supported by some previous studies as they have also found the existence of EKC's hypothesis in the shape of relationship between economy and environment from agricultural activities (13-19). Despite using different approach, a study found that the relationship between $\mathrm{CO}_{2}$ emission and the all-crops production in Pakistan results in an inverted U-shape [14], whereas other study found $\mathrm{CH}_{4}$ emission from the agriculture and economy growth in Argentina gave similar results using ARDL model [18]. This study is more so related to the results from [13] as they have found an evidence to the existence of EKC by estimating the relationship between the GRDP of agricultural labour and the emission obtained from agricultural activities using panel data model.

This study provides additional results by comparing the turning point and the average value of natural rubber production from major producers. According to [28], the turning p oint can be found by the differential of the first derivative of VPR and VPR ${ }^{2}$. Thereby the turning point can be calculated as follows:

$$
\text { Turning Point }=\frac{-\beta_{1}}{2 \beta_{2}}=\frac{-\left(1.32 * 10^{-6}\right)}{2 *-3.89 * 10^{-14}}=16,966,580.98
$$

From the calculation, we found that the turning point of the relationship between the $\mathrm{N}_{2} \mathrm{O}$ emission and the value of natural rubber production based on $\mathrm{EKC}$ is valued at 16,966,580. According to the explanation from [12], this can be interpreted as the $\mathrm{N}_{2} \mathrm{O}$ emission from the use of synthetic fertilizer in natural rubber plantations will start to decline after it reaches USD $16,966,580$ of the value of natural rubber production per year. Following is the comparison between the average value of natural rubber production from major producers and the EKC's turning point. 
Table 5. The average value of natural rubber production in major producing countries

\begin{tabular}{|c|c|c|}
\hline Country & Average value of natural rubber production & \multirow{2}{*}{ Turning Point } \\
\hline Thailand & $5,358,610.0$ & \\
\hline Indonesia & $1,563,022.8$ & \multirow{2}{*}{$16,966,580.98$} \\
\hline Viet Nam & $1,053,436.3$ & \\
\hline India & $1,124,386.2$ & \\
\hline Average & $2,320,240.3$ & \\
\hline
\end{tabular}

Source: Secondary data analysis

Table 5 shows that overall, the a vera ge va lue of natural rubber production from four major producing countries are still below the value of EKC's turning point. Based on the theory of EKC explained by [12], Thailand, Indonesia, Viet Nam, and India are still in the early stage of the curve where a country still focused on the production activities so the environmental condition was not the priority of that country. Based on the calculation shown in Table 5, Thailand, as the leading natural rubber producer, needs to multiplied their value of natural rubber production by 3 to 4 times to reach the turning point.

High value of an agricultural production can be achieved by increasing its productivity, or price, or both productivity and price. However, those are the two main problems of the natural rubber industry nowadays. Several studies found that the natural rubberproductivity is still low compared to other cash crops such as oil palm [29-31]. In fact, most of the natural rubber plantations in Thailand, Indonesia, Viet Nam, and India are owned by smallholders, where some of them use uncertified seedling planting material as well as their conventional cultivation practice. This is due to the limited capital of farmers to invent recommended practices and/or technology, making it difficult to reach the potential productivity perhectare land of natural rubber plantation. Therefore, it has been suggested that there is an emergence of allocating credit loan to the rural and a gricultural a rea so that the agroindustry can be well developed [32].

Low natural rubber price is another problem for the industry. With the reduced rubber price since 2011, it has caused some of the toughest era of the natural rubber smallholder farmers with their only capability to sell fresh rubber latex rather than the processed rubber [33]. A study modelled the world natural rubber price from Singapore SICOM Price and found that it involves some factors such as natural rubber production and consumption [34]. They explained that there is a positive relationship between the price and production and it was supported by the previous studies on similar topic. Therefore, there is an emergence of increasing natural rubber price as it would lead to the increase in rubber production and induce higher income for smallholders as well as the country.

\subsection{Better Fertilizer Management Practice}

Fertilizer is the essential source of nutrients for crops. It helps to increase the productivity of rubber crops [35]. However, the use of it should be carefully conducted because of environmental disadvantages obtained from the use of synthetic fertilizer. More important is because of the use of superior clones by many rubber plantations [36]. Superior clones has higher rate of productivity that requires a lot of nutrients obtained from the soil. As many 
nutrients have been drained by, it is important for providing some a dditional nutrients through fertilization.

Related to this, $\mathrm{N}_{2} \mathrm{O}$ emission can be found in the applied synthetic fertilizer during the cultivation process. $\mathrm{N}_{2} \mathrm{O}$ emission can be more dangerous compared to the infamous $\mathrm{CO}_{2}$ emission according to the higher coefficient of Global Warming Potential [8, 37, 38]. A study found that the $\mathrm{N}_{2} \mathrm{O}$ emission from rubber plantations comes from the use of synthetic fertilizer are $4 \mathrm{~kg} \mathrm{~N} / \mathrm{ha} /$ year with the $1.96 \%$ emission factor of $\mathrm{N}_{2} \mathrm{O}$ [39]. Therefore, in order to achieve higher outputs from the natural rubber cultivation while still maintain the environmentalcondition, it requires best management practice including strategy to mitigate $\mathrm{N}_{2} \mathrm{O}$ emissions form fertilization.

There are several ways to reduce the $\mathrm{N}_{2} \mathrm{O}$ emissions on a rubber plantation. It could be reduced by reducing fertilizer and adding DMPP (3, 4-Dimehylpyrazole phosphate) [40]. Although the addition of DMPP could reduce $\mathrm{N}_{2} \mathrm{O}$ emission by $40 \%$, this option is not commonly used on the field. The reduction about $20 \%$ of the prescribed amount of fertilizer could decrease the yield in the early cultivation stage. The other option to reduce emission from rubber plantation can be done by introducing a leguminous shrub called Flemingia macrophylla, which could significantly reduce the number of $\mathrm{N}_{2} \mathrm{O}$ emission [41]. There is also an innovation that has been developed to reduce $\mathrm{N}_{2} \mathrm{O}$ emission which is biochar. With the reduce of applied synthetic nitrogen, it could effectively reduce the $\mathrm{N}_{2} \mathrm{O}$ emission up to $73 \%$ over the third wet-dry cycle after 4 months of application [42]. However, the type of biochar and its compatibility with certain soil types are rarely studied on behalf of natural rubber plantations.

\section{Conclusions}

Natural rubber is one of the world's tradable commodities mostly coming from South East Asia and Latin America. It has contributed to the state's economic growth where Thailand, Indonesia, Viet Nam, and India are no exception. However, it can also contribute to the GHG emissions as coming from the use of synthetic fertilizer during the cultivation process. The nitrogen-based synthetic fertilizer can produce $\mathrm{N}_{2} \mathrm{O}$ emission which is one of the GHG emission's compounds.

From the findings of this study, we can conclude that this study found the evidence of EKC's hypothesis in the form of relationship between $\mathrm{N}_{2} \mathrm{O}$ emissions and the value of natural rubber production. The relationship results in an inverted U-shaped curve. This study also provides additional information as the major natural rubber producers have not yet reached the turning point of EKC. Hence, there is an emergence to the industry to increase its value of production while maintaining yet reducing the emission.

It is also confirmed that even though fertilizer has a pivotal role in optimizing rubber plant's growth, the fertilization activity should be carefully controlled and managed. Due to the less $\mathrm{N}_{2} \mathrm{O}$ emission, biochar might be an option to reduce the emission coming from the nitrogen-based synthetic fertilizer. However, due to the lack of biochar studies on natural rubber plantations, further researches are strongly suggested.

\section{References}

1. [FAO] Food and Agricultural Organization, Asia-Pacific Forestry Sector Outlook Study: The Utilization, processing and demand for Rubber wood as a source of wood supply, [Online] from http://www.fao.org/3/Y0153E/Y0153E05.htm (2000), [Accessed on April 22, 2021] 
2. [FAO] Food and Agricultural Organization, FAOSTAT, [Online] from http://www.fao.org/faostat/en (2021), [Accessed on April 23, 2021]

3. Nation Master, Top countries in natural rubbernet production, [Online] from https://www.nationmaster.com/nmx/ranking/natural-rubber-net-production (2020), [Accessed on February 15, 2021]

4. Grow Asia, Case study: Rubberin Indonesia, [Online] from http://exchange.growasia.org/system/files/200615 GA\%20Rubber\%20Report Digital \%20\%28Fina1\%29.pdf (2020), [Accessed on February 16, 2021]

5. I. R. J. Sari, J. A. Fatkhurrahman, Y. Andriani, N. Nasuka, JurnalRiset Teknologi Pencegahan Pencemaran Industri, 10, 36-42 (2019)

6. A. Virginia, T. Novianti, Journal of Developing Economies, 5 (2020) https://doi.org/10.20473/jde.v5i1.18609

7. I. Tiseo, Statista: Natural rubber top exporting countries distribution 2019, [Online] from https://www.statista.com/statistics/652796/distribution-of-the-lea ding-naturalrubber-exporters/ (2021), [Accessed on April 23, 2021]

8. [IPCC] Intergovernmental Panel on Climate Change, Summit 2007: Summary for Policymakers, [Online] from https://www.ipcc.ch/report/ar4/syr/ (2007), [Accessed on February 15, 2021]

9. [IPCC] IntergovernmentalPanel on Climate Change, Summit 2014: Full Report of IPCC Fifth Assessment, [Online] from https://www.ipcc.ch/report/ar5/wg3/ (2014), [Accessed on February 15, 2021]

10. W. Jawjit, C. Kroeze, S. Rattanapan, J. Cleaner Production, 18, 403-411 (2010)

11. S. Kuznets, American Economic Review, 49, 1-28 (1955)

12. T. Panayotou, Empirical Test and Policy Analysis of Environmental Degradation at Different Stages of Economic Development, Working Paper (1993)

13. A. H. Al Rosyid, Irham, J. H. Mulyo, Agro Ekonomi, 28, 95-111 (2017)

14. A. Ullah, D. Khan, Environ. Sci. Pollut. Res, 27, 320-336 (2020)

15. E. Zafeiriou, S. Sofios, X. Partalidou, Environ. Sci. Pollut. Res, 24, 15510-15520 (2017)

16. K. Ogundari, A. A. Ademuwagun, O. A. Ajao, IJSE, 44 (2017)

17. N. K. Dogan, AGRICECON, 62 (2016)

18. J. L. S. Cruz, L. E. S. Granda, M. L. P. Viteri, INNOVA Research Journal, 3, 165-179 (2018)

19. M. M. M. Uddin, Environmental and Sustainability Indicators, 7 (2020), https://doi.org/10.1016/j.indic.2020.100041

20. B. H. Baltagi, Econometric Analysis of Panel Data (John Wiley \& Sons, England, 2005)

21. D. N. Gujarati,Basic Econometrics (The Mc-Graw Hill, NY, 2003)

22. [FAO] Food and Agricultural Organization, Value of natural rubber production 2005 2018, [Online] from http://www.fao.org/faostat/en/\#data (2021), [Accessed on February 27, 2021]

23. K. Sa swattecha, C. Kroeze, W. Ja wjit, L. Hein, J. Cleaner Production, 150-169 (2015)

24. B. H. Prasetyo, D. A. Suriadikarta, Jurnal Litbang Pertanian, 25 (2006)

25. J. Saputra, Strategi pemupukan tanaman karet dalam menghadapi harga karet yang rendah, Warta Perkaretan, 37, 75-86 (2018) 
26. R. Adiwiganda, M. M. Siahaan, Tanah dan Pemupukan Tanaman Kelapa Sawit, Lembaga Pendidikan Perkebunan, 68 (1994)

27. A. A. Ogundipe, P. O. Alege, O. M. Ogundipe, Journal of Sustainable Development, 7, 165-180 (2014), http://dx.doi.org/10.5539/jsd.v7n4p165

28. Y. Zhang, X. Chen, Y. Wu, C. Shuai, L. Shen, EnvironmentalImpact Assessment Review, 79 (2017) DOI: 10.1016/j.eiar.2019.106303

29. B. Arifin, ASEAN Journal of Economics, Management and Accounting, 1, 81-100 (2013)

30. A, Setiyanto, Analisis Efisiensi Produksi Kelapa Sawit, [Online] from http://pse.litbang.pertanian.go.id (2015), [Accessed on April 17, 2021]

31. R. S. Perdana, Forum Penelitian Agro Ekonomi, 37 (2009), http://dx.doi.org/10.21082/fae.v37n1.2019.25-39

32. G. Wirakusuma, Irham, S. Hartono, J. Mulyo, IOP Conf. Ser.: Earth Environ. Sci., 383 (2019), DOI:10.1088/1755-1315/383/1/012021

33. A Zeani, Juraemi, Rudiansyah, M. Saleh, Pengembangan Karet Studi Kasus di Kutai Timur, Mulawarman University Press (2007)

34. Y. C. Fong, A. A. Khin, C. S. Lim, Asian Journal of Economic Modelling, 6, 408-418 (2018) DOI:10.18488/journal.8.2018.64.403.418

35. S. R. Achmad, I. Susetyo, Pengaruh proses pencampuran dan cara aplikasi pupuk terhadap kehilangan unsurN, Warta Perkaretan, 33, 29-34 (2014)

36. R. Purnamayanu, N. Asni, Teknologi Pemupukan Karet Unggul dan Lokal Spesifik Loaksi, Balai Pengkajian Teknologi (BPTP) Jambi(2013)

37. K. L. Denman, G. Brasseur, Contribution of Working Group I to the Fourth Assessment Report of the IntergovernmentalPanel on Climate Change 2007, 501-568 (2007)

38. P. Forster, V. Ramaswamy, P. Artaxo, T. Berntsen, R. Betts, D. W. Fahey, R. van Dorland, Contribution of Working Group I to the Fourth Assessment Report of the IntergovernmentalPanel on Climate Change 2007, 131-217 (2007)

39. WJ. Zhou, Hl. Ji, J. Zhu, YP. Zhang, LQ. Sha, YT. Liu, X. Zhang, W. Zhao, Yx. Dong, XL. Bai, YX. Lin, JH. Zhang, XH. Zheng, Scientific Reports, 6 (2016)

40. H. Pfab, Nitrous oxide emission and mitigation strategies: Measurements on an intensively fertilized ve getable cropped loamy soil, Dissertation, (2011)

41. X. Rao, C. A. Liu, J. W. Tang, Y. Nie, M. Y. Liang, W. J. Shen, K. H. M. Siddique, Forest Ecology and Management, $\mathbf{4 8 0}$ (2021) https://doi.org/10.1016/j.foreco.2020.118665

42. B. P. Singh, B. J. Hatton, B. Singh, A. L. Cowie, A. Kathuria, Journal of EnvironmentalQuality, 39, 1224-1235 (2010) https://doi.org/10.2134/jeq2009.0138 